\title{
Wind energy potential and cost estimation of wind energy conversion systems (WECSs) for electricity generation in the eight selected locations of Tigray region (Ethiopia)
}

\author{
Satyanarayana Gaddada ${ }^{1}$ and Shiva Prashanth Kumar Kodicherla ${ }^{2^{*}}$
}

\begin{abstract}
Wind energy is one of the most cost-effective forms of renewable energy source with significant increment in yearly installed capacities all around the world. In this study, three commercial wind turbines, namely POLARIS P15-50, POLARIS P50-500 and VESTAS V1 10-2.0, were chosen as large-scale wind energy conversion systems (WECSs) for technical assessment of electric power generation in eight selected locations spreading across the Tigray region of Ethiopia. The economic evaluations of these three WECSs for electric power generation in the selected locations were estimated using present value of cost (PVC) method. These results showed that the highest capacity factor is obtained as $7.873 \%$ using VESTAS V1 10-2.0 at Mekele, while the lowest as 0.002 \% using POLARIS P15-50 at Shire. Average minimum cost per kWh obtained at Mekele was $0.0011 \$ / \mathrm{kWh}$ using VESTAS V1 10-2.0, while the highest average cost was $7.3148 \$ / \mathrm{kWh}$ using POLARIS P15-50 at Shire. Furthermore, it can be suggested that Atsbi, Chercher, Mekele and Senkata were most profitable for electrical and mechanical applications than hydropower cost in the country.
\end{abstract}

Keywords: Wind energy, Tigray region, Ethiopia, PVC, WECS

\section{Background}

Wind is an inexhaustible and most accepted energy resource, which does not cause any pollution in electricity production (Ucar and Balo 2009). During past two decades, global wind energy has been experiencing a rapid intensification among the available renewable energy resources (Murat and Mustafa Seedar 2009). In developing nations, renewable energy sources have been gaining prominence with increasing efficiency of renewable energy technologies and the associated decrement in production costs. However, among these energy resources, wind energy is fetching the world's fastest growing renewable energy source; its worldwide acceptance as a spotless source of energy can be attributed to

\footnotetext{
*Correspondence: prashanth1024@gmail.com

${ }^{2}$ Department of Civil Engineering, College of Engineering

and Technology, Wollega University (WU), Nekemte, Oromia Region,

Ethiopia

Full list of author information is available at the end of the article
}

several policies made to promote renewable energy sources, security of supply, biodiversity concerns, ecological awareness and other socioeconomic factors (Akdag and Guler 2010).

In recent days, demand for energy production in Ethiopia has increased rapidly due to escalating population and industrialization. However, it is well endowed with abundant energy resources such as hydropower, solar, wind, biomass, natural gas and geothermal to develop, transform and utilize these resources for optimal economic development. Exploitable energy resources of Ethiopia are given in Table 1 [Ministry of Water and Energy (MoWE) 2011; Ethiopian Electric Power Corporation (EEPCo) 2011].

Lack of organized data on wind energy potential of the country covering entire regions has been one of the reasons for restricted applications in Ethiopia. But in recent days, wind energy resources were identified in several regions. The government has committed itself to generate power from wind energy plants by constructing 
Table 1 Exploitable potential of energy resource in Ethiopia

\begin{tabular}{llll}
\hline S. no & Resource & Unit & $\begin{array}{l}\text { Exploitable } \\
\text { potential }\end{array}$ \\
\hline 1 & Biomass & Million metric ton/year & 75 \\
2 & Hydropower & MW & 45,000 \\
3 & Solar & kWh per meter square per day & $5-6$ \\
4 & Wind & MW & 10,000 \\
5 & Geothermal & MW & 5000 \\
6 & Natural gas & Billion cubic meter & 113 \\
7 & Coal & Million ton & 400 \\
\hline
\end{tabular}

eight wind farms over the 5-year Growth and Transformation Plan (GTP) period between 2011 and 2015 [Growth and Transformation Plan (GTP) 2010]. In terms of Gross Domestic Product (GDP) per capita, Ethiopia is 174th place of 179, and in terms of Human Development Index (HDI), it is placed 169th of 177 (Breyer et al. 2009). Among the $85 \%$ of Ethiopian population living in rural areas, only $16 \%$ have total access to electricity. The consumption of electricity in urban areas is less than 50 $\mathrm{kWh}$ per year, while rural areas are negligible about $2 \%$ (Hadagu 2006; Dalelo 2003).

There are quite a lot of investigations concentrated on evaluation of wind characteristics and feasibility analysis of various wind projects in the whole world (Acker et al. 2007; Rehman et al. 2007; Shata and Hanitsch 2006; Genç and Gökçek 2009; Bagiorgas et al. 2007). The first national-level study on wind energy potential assessment was done by Italian company CESEN-ANSALDO group in mid-1980's in Ethiopia. However, this estimation was based on theoretical analysis with inadequate ground data measurements. The estimation by CESEN categorized three broad wind regions with an increasing gradient in wind speed from west to east with maximum concentration near Djibouti border on the Red Sea Coast (CESEN-ANSALDO 1986). The second nationallevel study of wind energy resource in the country was conducted in 2007 by Solar and Wind Energy Resource Assessment (SWERA) (Ethiopian Rural Energy Development and Promotion Center 2007). This program was sponsored jointly by the United Nations Environmental Program (UNEP) and Global Environment Facility (GEF). The long-term wind speed measurements at a given location provide fundamental information for an assessment of wind power availability and the economic viability of Wind Energy Conversion Systems (WECSs) for its technical design. A Geographical Information System (GIS) map was generated using SWERA wind resource data to indicate the annual mean wind power density of any particular location in Ethiopia.
Wind energy resources in Ethiopia without excluding protected areas are shown in Fig. 1 [Ethiopian Resource Group (ERG) 2009]. This geographical distribution of wind diagram also helps us to promote the locations with poor-to-excellent wind resources in the country. The classification of wind resources and extent of associated land areas as given by SWERA are presented in Table 2. As recommended, further ground measurements are necessary to verify the estimation when planning and deployment of wind turbines are concerned to a particular site. The wind regions of the country are classified into seven broad categories and land areas; under each category, it is calculated and presented at regional level indicating suitable areas for various purposes of wind energy development. However, it can be clearly observed from Fig. 1 that, the annual mean power densities are falling under class 1 (poor); an attempt has been made to investigate the wind energy resource assessment in eight selected locations of Tigray region in Ethiopia (See Fig. 2).

It is fact that very limited potentials of different renewable energy resources across all the regions of Ethiopia have been studied (Shiva Prashanth and Satyanarayana 2015; Mulugeta et al. 2013; Getachew and Getnet 2012). However, research work covering only few sites in Ethiopia has been carried out on the economic viability of electricity generation by wind resources (Bekele and Palm 2009). Hence, the need for thorough economic assessment of wind power generation in Ethiopia is necessary as the investor's hope and expect solely on the long-term security of income from the wind energy investments.

The first part of this study covers a brief review of wind resource assessment in the selected locations; the second part focuses on the analysis of electricity generation through the respective power and energy output of the turbines together with the capacity factors, while the third part is concentrated on economic analysis of the selected sites using method of Present Value of Cost (PVC).

\section{Mathematical model}

The feasibility of wind energy resource at any site can be characterized by various mathematical approaches. In the current study, Weibull distribution function has been used as a mathematical tool to assess wind power potential, which is presented and discussed in the following sections.

\section{Wind energy potential}

A 12-year (2002-2014) monthly wind speed data were obtained from National Meteorological Agency (NMA), Mekele, for the selected sites: Adigrat, Adwa, Atsbi, Chercher, Maychew, Mekele, Senkata and Shire. 


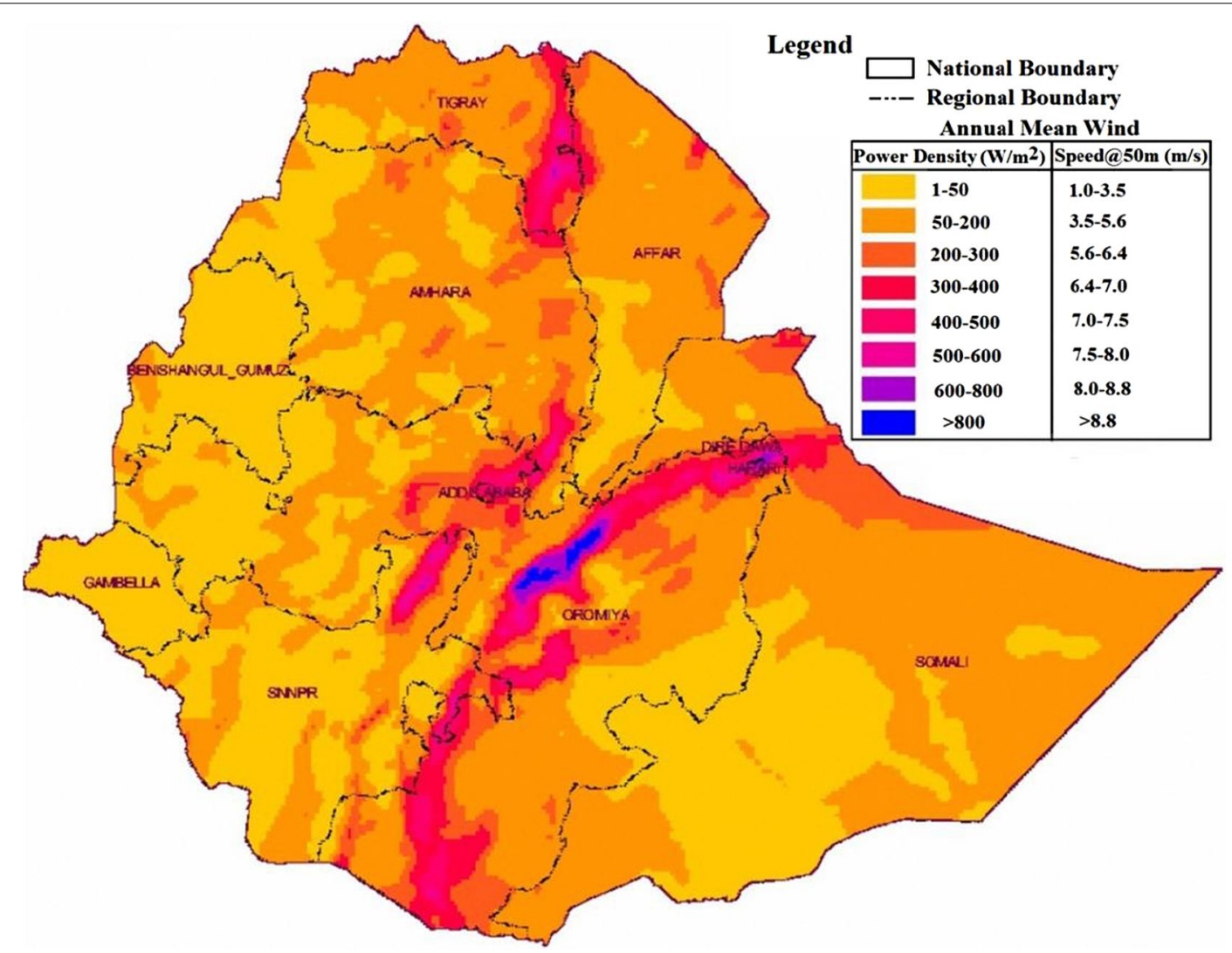

Fig. 1 Annual mean wind power density of Ethiopia at $50 \mathrm{~m}$ height without excluding protected areas

Table 2 Classification of wind resource and extent of associated land areas

\begin{tabular}{|c|c|c|c|c|}
\hline Wind resource category & Wind class & Wind power density $\left(\mathrm{W} / \mathrm{m}^{2}\right)$ & Wind speed at $50 \mathrm{~m}(\mathrm{~m} / \mathrm{s})$ & Total area $\left(\mathrm{km}^{2}\right)$ \\
\hline Poor & 1 & 50-200 & $3.5-5.6$ & 564,600 \\
\hline Marginal & 2 & $200-300$ & $5.6-6.4$ & 96,801 \\
\hline Moderate & 3 & $300-400$ & $6.4-7.0$ & 42,935 \\
\hline Good & 4 & $400-500$ & $7.0-7.5$ & 23,975 \\
\hline Excellent & 5 & $500-600$ & $7.5-8.0$ & 6529 \\
\hline Excellent & 6 & $600-800$ & $8.0-8.8$ & 3814 \\
\hline Excellent & 7 & Above 800 & Above 8.8 & 1715 \\
\hline \multicolumn{4}{|c|}{ Total area covered by poor-to-excellent wind regions } & 740,376 \\
\hline
\end{tabular}

Geographical coordinates of the eight selected stations, where wind speed data were captured at $10 \mathrm{~m}$ height by a cup-generator anemometer are given in Table 3.

A well-recognized paramount two-parameter Weibull probability distribution function is adopted in this investigation for wind speed breakdown, because it gives an enhanced fit for the measured monthly probability density distribution than other statistical functions (Akdag et al. 2010; Elliott et al. 1987; Akpinar and Akpinar 2005). The probability distribution function can be expressed as:

$$
f(v)=\frac{\mathrm{d} F(v)}{\mathrm{d} v}=\frac{k}{c}\left(\frac{v}{c}\right)^{k-1} e^{-\left(\frac{v}{c}\right)^{k}}
$$

where $k$ and $c$ are the Weibull shape and scale parameters, respectively. The integration of Weibull probability density function is known as cumulative distribution function and can be expressed as:

$$
F(v)=\int_{0}^{v} f(v) \mathrm{d} v=1-e^{-\left(\frac{v}{c}\right)^{k}}
$$




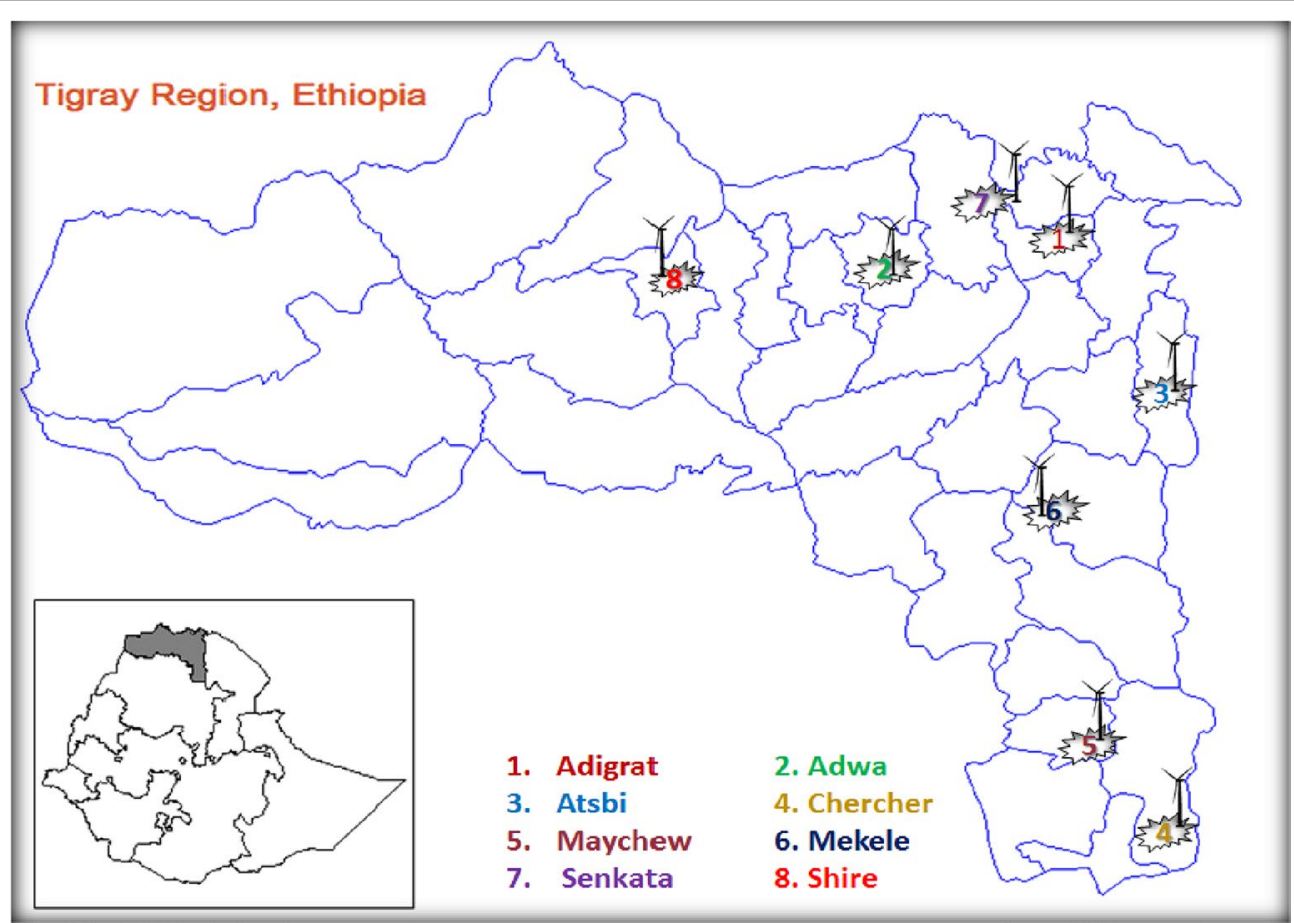

Fig. 2 Map of Ethiopia showing the data collected stations in Tigray region of Ethiopia

Table 3 Geographical locations of the eight selected locations

\begin{tabular}{|c|c|c|c|c|}
\hline S. no & Locations & Latitude ${ }^{\circ} \mathrm{N}$ & Longitude ${ }^{\circ} \mathrm{E}$ & Elevation $(\mathrm{m})$ \\
\hline 1 & Adigrat & 14.27 & 39.45 & 2457 \\
\hline 2 & Adwa & 14.17 & 38.90 & 1985 \\
\hline 3 & Atsbi & 13.87 & 39.73 & 2630 \\
\hline 4 & Chercher & 12.53 & 39.77 & 1767 \\
\hline 5 & Maychew & 12.47 & 39.32 & 2479 \\
\hline 6 & Mekele & 13.29 & 39.28 & 2084 \\
\hline 7 & Senkata & 14.32 & 39.34 & 2480 \\
\hline 8 & Shire & 14.60 & 38.17 & 1953 \\
\hline
\end{tabular}

In general, Weibull parameters can be derived from the following methods such as Weibull probability plotting paper, standard deviation method (STDM), method of moments (MOM), least square regression method (LSRM), maximum likelihood method (MLM) and energy pattern factor method (EPFM). Owing to an intrinsic worth over the other commonly used methods, EPFM was used in this study (Akdag and Dinler 2009). Energy pattern factor (EPF) can be expressed as the mean of sum of cubes of all individual wind speeds considered in a sample divided by the cube of mean wind speed of the sample (Centre for Wind Energy Technology 2011) given as:

$$
\mathrm{EPF}=\frac{1}{(\bar{v})^{3}}\left(\sum_{i=1}^{n} \frac{v_{i}^{3}}{n}\right)
$$

where $v_{\mathrm{i}}$ is the wind speed in meters per second for $i$ th observation, $n$ is the number of wind speed samples considered, and $\bar{v}$ is the monthly mean wind speed in meter per second. The monthly Wind Power Density (WPD) is given as:

$$
\mathrm{WPD}=0.5 \rho\left(\sum_{i=1}^{n} \frac{v_{i}^{3}}{n}\right)
$$

The monthly mean air density, $\rho$, is at turbine hub height in kilogram per cubic meter. Substituting Eq. 3 in Eq. 4, EPF can be expressed as:

$$
\mathrm{EPF}=\frac{1}{\left(\bar{v}^{3}\right)} \times\left(\frac{\mathrm{WPD}}{0.5 \times \rho}\right)
$$

Shape parameter can be calculated using EPF, which is expressed as (Akdag and Guler 2010; Rocha et al. 2012):

$$
\begin{aligned}
& k=1+\frac{3.69}{(\mathrm{EPF})^{2}} \\
& c=\frac{\bar{v}}{\Gamma\left(1+\frac{1}{k}\right)}
\end{aligned}
$$


For simplicity, the gamma function is defined as (Jowder 2009; Ouammi et al. 2010):

$$
\Gamma(x)=\int_{0}^{\infty} t^{x-1} e^{-t} \mathrm{~d} t
$$

Instead, scale factor can also be obtained mathematically as (Balouktsis et al. 2002):

$$
c=\frac{\bar{v} k^{2.6674}}{0.184+0.816 k^{2.78855}}
$$

Results of the annual wind speed characteristics of selected locations are presented in Table 4. The annual mean wind speed ranges between 1.044 and $3.488 \mathrm{~m} / \mathrm{s}$ at Shire and Mekele. The maximum annual mean power density $\left(P_{\mathrm{D}}\right)$ and energy densities $\left(E_{\mathrm{D}}\right)$ are obtained as $35.129 \mathrm{~W} / \mathrm{m}^{2}$ and $306.06 \mathrm{kWh} / \mathrm{m}^{2}$ at Mekele, while the minimum values are obtained as $0.857 \mathrm{~W} / \mathrm{m}^{2}$ and $7.44 \mathrm{kWh} / \mathrm{m}^{2}$ at Shire, respectively. The Weibull shape parameter $k$ ranges from 2.88 at Adwa to 4.24 at Atsbi, while the scale factor, c ranges from $1.16 \mathrm{~m} / \mathrm{s}$ at Shire to $3.86 \mathrm{~m} / \mathrm{s}$ at Mekele. However, based on SWERA wind resource classification scheme, it can be concluded that wind resources in all selected locations are falling into class 1 (poor). It can further be suggested that installation of taller wind turbines can contribute for wind power development in this region. Thus, all the locations can be considered as suitable for different wind energy applications (such as grid-connected electricity and stand-alone water pumping).

\section{Extrapolation of wind speeds at different turbine hub heights}

Wind speeds used in this study were captured at $10 \mathrm{~m}$ height from the ground surface level. However, it is distinguished that the wind speed at hub height is of interest for wind power application. Therefore, the available wind speeds are extrapolated to the turbine hub heights. The following power law expression is given as (Akpinar and Akpinar 2005):

$$
\frac{v}{v_{\mathrm{o}}}=\left(\frac{h}{h_{\mathrm{o}}}\right)^{\propto}
$$

where $v$ is the wind speed at height $h ; v_{\mathrm{o}}$ is the wind speed at original height $h$; and $\alpha$ is the surface roughness coefficient and lies in the range $0.05-0.5$, but in most of the cases ' $\alpha$ ' is assumed to be 0.143 (or 1/7). It can be determined as (Ucar and Balo 2009):

$$
\propto=\left[0.37-0.088 \ln \left(v_{\mathrm{o}}\right)\right] /\left[1-0.88 \ln \left(\frac{h_{\mathrm{o}}}{10}\right)\right]
$$

Moreover, the Weibull probability density function can be used to obtain the extrapolated values of wind speeds at different hub heights. The boundary layer development and the effect of ground are nonlinear with respect to Weibull parameters $\mathrm{k}$ and $\mathrm{c}$. It can be expressed as (Justus et al. 1978):

$$
c(h)=c_{\mathrm{o}}\left(\frac{h}{h_{\mathrm{o}}}\right)^{z}
$$

$$
k(h)=k_{\mathrm{o}}\left[1-0.88 \ln \left(\frac{h_{\mathrm{o}}}{10}\right)\right] /\left[1-0.88 \ln \left(\frac{h}{10}\right)\right]
$$

where $k_{o}$ and $c_{\mathrm{o}}$ are the shape and scale parameters at measured height $h_{\mathrm{o}}$ and the hub height $h$. The exponent $z$ is given in Ohunakin et al. (2011) as:

$$
z=\left[0.37-0.088 \ln \left(c_{\mathrm{o}}\right)\right] /\left[1-0.088 \ln \left(\frac{h}{10}\right)\right]
$$

\section{Evaluation of power output for WECS}

A wind turbine is composed of an electric generator mounted on a suitable tower, a wind turbine controller, a battery bank, inverter and balance system. Considering such a compiled system, annual energy production of a selected site can be calculated using wind speed data belonging to that site and power curves related to wind turbines (Burton et al. 2001; Chang and Tu 2007). In general, WECS can operate its maximum efficiency only if it is designed for a particular site, because of rated power,

Table 4 Wind characteristics of the eight selected locations

\begin{tabular}{lllccc}
\hline S. no & Locations & $\begin{array}{l}\text { Wind speed } \\
(\mathbf{m} / \mathbf{s})\end{array}$ & $\begin{array}{l}\text { Average power } \\
\text { density }\left(\mathbf{W} / \mathbf{m}^{\mathbf{2}}\right)\end{array}$ & $\begin{array}{l}\text { Average energy } \\
\text { density }\left(\mathbf{k W h} / \mathbf{m}^{\mathbf{2}}\right)\end{array}$ & $\boldsymbol{k}(\mathbf{m} / \mathbf{s})$ \\
\hline 1 & Adigrat & 1.183 & 1.1932 & 10.4102 & 1.3186 \\
2 & Adwa & 1.114 & 1.0693 & 9.3161 & 3.3785 \\
3 & Atsbi & 2.589 & 11.0868 & 97.0776 & 2.8844 \\
4 & Chercher & 2.557 & 11.0881 & 96.9703 & 4.2404 \\
5 & Maychew & 1.387 & 2.4298 & 21.4644 & 3.7884 \\
6 & Mekele & 3.488 & 35.1295 & 306.0615 & 3.7031 \\
7 & Senkata & 2.184 & 7.2038 & 62.6984 & 3.7456 \\
8 & Shire & 1.044 & 0.8579 & 7.4484 & 3.5306 \\
\hline
\end{tabular}


and cut-in and cut-off wind speeds must be defined based on the site wind characteristics. One of the important performance parameters of wind turbines is the capacity factor $\left(C_{\mathrm{f}}\right)$, which represents the fraction of average power output $\left(P_{\text {e,avg }}\right)$ over a period to the rated electrical power $\left(P_{\mathrm{eR}}\right)$ (Akpinar and Akpinar 2005). The $P_{\mathrm{e}, \mathrm{avg}}$ and $C_{\mathrm{f}}$ of a wind turbine can be calculated using Eqs. (15) and (16) (Shiva Prashanth and Satyanarayana 2015):

$$
\begin{aligned}
& P_{\mathrm{e}, \text { average }}=P_{\mathrm{eR}}\left\{\frac{e^{-\left(\frac{Q_{c}}{c}\right)^{k}}-e^{-\left(\frac{Q_{r}}{c}\right)^{k}}}{\left(\frac{Q_{r}}{c}\right)^{k}-\left(\frac{Q_{c}}{c}\right)^{k}}-e^{-\left(\frac{Q_{f}}{c}\right)^{k}}\right\} \\
& C_{\mathrm{f}}=\frac{P_{\mathrm{e}, \text { avg }}}{P_{\mathrm{eR}}}
\end{aligned}
$$

Accumulated annual energy output $\left(E_{\text {out }}\right)$ is expressed in Eq. (17) (Ucar and Balo 2009):

$$
E_{\text {out }}=C_{\mathrm{f}} E_{\text {rated }}
$$

where $Q_{\mathrm{c}}, Q_{\mathrm{r}}$ and $Q_{\mathrm{f}}$ are the cut-in wind speed, rated wind speed and cut-off wind speeds, respectively, whereas $P_{\text {e,avg }}$ determines the total energy production and total income. For an investment, wind power should be costeffective and it is suggested to have the capacity factor greater than 0.25 (Mathew 2006).

\section{Analysis of wind energy cost}

Feasibility of a wind energy production plants depends on its ability to generate energy at a low operating cost (Genç and Gökçek 2009). According to Redlinger et al. (2006), the main parameters governing the economics of wind power include an investment cost (including auxiliary costs for foundation and grid connection), operation and maintenance cost, electricity production, turbine lifetime and discount rate. These factors may vary from country to country and region to region. However, among all the parameters listed, the electricity production using WECS and their investment costs are the most important factors. Apart from the cost of the wind turbine, which is set by the manufacturers, the specific cost of a wind turbine varies from one manufacturer to another manufacturer. The specific cost of a wind turbine can be taken by considering band interval (minimum and maximum values) as presented in Table 5 (Adaramola et al. 2011).

The economics of WECS principally depends on the operator-specific boundary conditions. A simplified approach to calculate the cost of electricity per $\mathrm{kWh}$ includes investment cost, operation and maintenance cost and capital cost. The investment cost of a wind turbine includes basic cost, extras, foundation, grid
Table 5 WECS cost band

\begin{tabular}{llll}
\hline $\begin{array}{l}\text { Wind turbine } \\
\text { size }(\mathbf{k W})\end{array}$ & $\begin{array}{l}\text { Min. specific } \\
\text { cost }(\mathbf{\$} / \mathbf{k W})\end{array}$ & $\begin{array}{l}\text { Max. specific } \\
\text { cost }(\mathbf{\$} / \mathbf{k W})\end{array}$ & $\begin{array}{l}\text { Average specific } \\
\text { cost }(\mathbf{\$} / \mathbf{k W})\end{array}$ \\
\hline $10-20$ & 2200 & 3000 & 2600 \\
$20-200$ & 1250 & 2300 & 1775 \\
200 and above & 700 & 1600 & 1150 \\
\hline
\end{tabular}

connection, planning and licensing. The operation and maintenance cost includes repair, insurance, monitoring and management, while the capital cost consists of interest and repayment of loan.

Numerous approaches have already been employed in the literature for evaluation of wind energy cost. In fact, the PVC method is adopted in this work because it considers the dynamic development of the relevant economic factors and different occurrences of costs and income are taken into account regardless of whether the money has been or will be paid or received in the past or in the future through deduction of accrued interest (discounting) of all payment flows to a common reference time (Hau 2006).

According to Shata and Hanitsch (2006), the PVC is expressed as:

$\mathrm{PVC}=I+C_{\mathrm{omr}}\left[\frac{1+i}{r-i}\right] \times\left[1-\left(\frac{1+i}{1+r}\right)^{t}\right]-S\left(\frac{1+i}{1+r}\right)^{t}$

where $I$ is the investment cost, $C_{\text {omr }}$ is the operation, maintenance and repair cost, $i$ is the inflation rate, $r$ is the interest rate, $t$ is the lifetime of the machine (in years) and $S$ is the scrap value.

The following assumptions are usually considered (Shata and Hanitsch 2006; Habali et al. 1987; Sarkar and Hussain 1991):

(a) The investment cost (I) includes the wind turbine's price plus the cost of civil work and connecting cables to the grid ( $20 \%$ of the basic cost).

(b) Operation, maintenance and repair cost $\left(C_{\text {omr }}\right)$ was considered to be $25 \%$ of the annual cost of wind turbine (machine price/lifetime) and must be escalated with the general inflation rate.

(c) According to Ethiopian context, the inflation rate $(i)$ and interest rates $(r)$ are taken as 10.4 and $5.08 \%$, respectively.

(d) The machine lifetime $(t)$ is assumed to have only 20 years.

(e) Scrap value $(S)$ is taken as $10 \%$ of the investment cost (machine and civil work). 


\section{Results and discussion}

The electrical power output of WECS and the cost analysis of electricity production using PVC approach in the chosen locations are presented and discussed briefly in the following sections.

\section{Electrical power output of the WECS}

The characteristics of three selected commercial wind turbines (POLARIS P15-50, POLARIS P50-500 and VESTAS V110-2.0 each with rated power $\left(P_{\mathrm{r}}\right) 50,500$ and $2000 \mathrm{~kW}$ ) are presented in Table 6.

The factors influencing energy produced by WECS at any given site during the related time period are power response of the WECS to different wind velocities, wind regimes and wind speed distributions (Genç and Gökçek 2009). In this study, the annual average wind power and wind energy output together with the capacity factors are computed using Eqs. (15)-(17), which are furnished in Table 6 . The extrapolated values of Weibull parameters $k$ and $c$ at respective turbine hub heights of 30,50 and $80 \mathrm{~m}$ are presented in Table 7 . These are computed to assess the performance of selected wind turbines for the chosen locations. Figure 3 presents the annual mean wind speeds at different hub heights for all the chosen locations. At $80 \mathrm{~m}$ hub height, the annual mean wind speeds for Adigrat, Adwa, Atsbi, Chercher, Maychew, Mekele, Senkata and Shire are 2.00, 1.88, 4.38, 4.32, 2.35, 5.91, 3.70 and $1.76 \mathrm{~m} / \mathrm{s}$, respectively.

It can be observed that the accumulated power output ranges from $0.033 \mathrm{~kW} /$ year at Shire using POLARIS P1550 to $487.766 \mathrm{~kW} /$ year at Mekele using VESTAS V1102.0, respectively. Next to Mekele, Atsbi and Chercher can be expected to have higher amount of power outputs using VESTAS V110-2.0 (Table 8). This may be evidently attributed to the high turbine hub height and rated power, which is higher than that of other selected wind turbine models.

The annual energy output of a wind turbine can also be expressed by considering the $C_{\mathrm{f}}$ of WECS in a chosen

Table 6 Characteristics of the selected WECS

\begin{tabular}{llll}
\hline Turbine specifications & POLARIS & & VESTAS \\
\cline { 2 - 3 } & P15-50 & P50-500 & V110-2.0 \\
\hline Hub height $(\mathrm{m})$ & 30 & 50 & 80 \\
Rated power, $P_{\mathrm{r}}(\mathrm{kW})$ & 50 & 500 & 2000 \\
Rotor diameter $(\mathrm{m})$ & 15.2 & 50 & 54 \\
Number of blades & 3 & 3 & 3 \\
Cut-in wind speed, $Q_{\mathrm{c}}(\mathrm{m} / \mathrm{s})$ & 2.5 & 2.5 & 3 \\
Rated wind speed, $Q_{\mathrm{r}}(\mathrm{m} / \mathrm{s})$ & 10 & 12 & 11.5 \\
Cut-off wind speed, $Q_{\mathrm{f}}(\mathrm{m} / \mathrm{s})$ & 25 & 25 & 20 \\
\hline
\end{tabular}

location. In general, the value of $C_{\mathrm{f}}$ can be affected by the intermittent nature of wind, machine availability and turbine efficiency. In practice, usually it ranges between 20 and $70 \%$. From Table 8, the highest capacity factor is obtained as $7.873 \%$ using VESTAS V110-2.0 at Mekele, while the lowest as $0.002 \%$ using POLARIS P15-50 at Shire. Among the selected locations, Shire has least amount of power output using all selected wind turbine models. The two sites (i.e., Shire and Mekele) have the lowest and highest annual power and energy outputs, respectively, using the three selected wind turbines. In addition, VESTAS V110-2.0 wind turbine model produces the largest energy for all the selected locations and is considered to be best among the three turbines for energy productions. Moreover, annual energy output as indicated in Fig. 4 showed that energy yield is reliant on the availability and strength of the wind speed at a given site and the WECS used. Hence, Mekele exhibited the best site in all the selected locations in this study.

\section{Present value of cost (PVC) of electricity}

WECS can be classified into four broad sizes such as micro (0-1.5 kW), small (1.5-20 kW), medium (20$200 \mathrm{~kW})$ and large $(>200 \mathrm{~kW})$ depending on the rated power (Ministry of Natural Resources, Canada, 19972004). The systems considered in this study are medium to large in size. The cost of any WECS can be expressed in terms of cost per kW. The specific cost of system based on the rated power was taken from Adaramola et al. (2011), as given in Table 5.

Table 9 shows the cost of unit energy per kWh based on the PVC method of analysis computed using Eq. 18 for the three selected wind turbines in the chosen locations. The least value of electricity production cost is obtained at Mekele as $0.0011 \$ / \mathrm{kWh}$ with the minimum cost of wind turbine, while maximum cost is observed at Shire as $7.3148 \$ / \mathrm{kWh}$ using VESTAS V110-2.0 and POLARIS P50-500 wind turbine models, respectively. Furthermore, the highest costs of unit energy per kWh using the maximum specific cost of wind turbine (Table 5) are obtained using VESTAS V110-2.0 turbine as \$0.2002, 0.1245, $0.0087,0.0058,0.1008,0.0015,0.0092$ and $0.8824 / \mathrm{kWh}$ at Adigrat, Adwa, Atsbi, Chercher, Maychew, Mekele, Senkata and Shire, respectively. Moreover, it can be recognized that Mekele has moderately considerable wind energy resource among the selected locations and is least considered in place like Atsbi and Chercher. However, Mekele can be considered as economically viable site with respect to average PVC values for any of the adopted wind turbine models. According to Ethiopian Electric Power Corporation (EEPCo), the tariffs for average cost per kWh domestic usage of electricity as on October 21, 
Table 7 Extrapolation of Weibull parameters at the respective turbine hub heights

\begin{tabular}{|c|c|c|c|c|c|c|c|c|c|c|}
\hline \multirow[t]{2}{*}{ Location } & & \multirow[t]{2}{*}{$z$} & \multicolumn{4}{|l|}{$k$} & \multicolumn{4}{|l|}{$c(\mathrm{~m} / \mathrm{s})$} \\
\hline & & & $10 \mathrm{~m}$ & $30 \mathrm{~m}$ & $50 \mathrm{~m}$ & $80 \mathrm{~m}$ & $10 \mathrm{~m}$ & $30 \mathrm{~m}$ & $50 \mathrm{~m}$ & $80 \mathrm{~m}$ \\
\hline \multirow[t]{12}{*}{ Adigrat } & January & 0.35 & 4.1300 & 4.5720 & 4.8114 & 5.0550 & 1.1401 & 1.6746 & 2.0025 & 2.3605 \\
\hline & February & & 3.5615 & 3.9426 & 4.1491 & 4.3592 & 1.4026 & 2.0603 & 2.4636 & 2.9041 \\
\hline & March & & 2.9835 & 3.3028 & 3.4758 & 3.6517 & 1.3912 & 2.0436 & 2.4436 & 2.8806 \\
\hline & April & & 3.5612 & 3.9423 & 4.1488 & 4.3588 & 1.7425 & 2.5596 & 3.0606 & 3.6079 \\
\hline & May & & 3.1403 & 3.4764 & 3.6585 & 3.8437 & 1.3764 & 2.0218 & 2.4176 & 2.8498 \\
\hline & June & & 3.9878 & 4.4146 & 4.6458 & 4.8810 & 1.9112 & 2.8073 & 3.3569 & 3.9571 \\
\hline & July & & 2.8632 & 3.1697 & 3.3357 & 3.5045 & 1.6994 & 2.4963 & 2.9849 & 3.5187 \\
\hline & August & & 3.0251 & 3.3488 & 3.5242 & 3.7026 & 1.1139 & 1.6363 & 1.9566 & 2.3064 \\
\hline & September & & 3.5785 & 3.9615 & 4.1689 & 4.3800 & 0.9104 & 1.3374 & 1.5992 & 1.8851 \\
\hline & October & & 3.7279 & 4.1269 & 4.3430 & 4.5629 & 1.0386 & 1.5256 & 1.8242 & 2.1504 \\
\hline & November & & 2.3553 & 2.6074 & 2.7440 & 2.8829 & 1.1015 & 1.6181 & 1.9348 & 2.2808 \\
\hline & December & & 3.6272 & 4.0154 & 4.2257 & 4.4396 & 0.9955 & 1.4622 & 1.7485 & 2.0611 \\
\hline \multirow[t]{12}{*}{ Adwa } & January & 0.35 & 2.7517 & 3.0462 & 3.2057 & 3.3680 & 0.7872 & 1.1563 & 1.3827 & 1.6299 \\
\hline & February & & 3.4350 & 3.8027 & 4.0018 & 4.2044 & 1.1568 & 1.6992 & 2.0319 & 2.3952 \\
\hline & March & & 3.1619 & 3.5003 & 3.6836 & 3.8701 & 1.2415 & 1.8237 & 2.1807 & 2.5707 \\
\hline & April & & 2.4296 & 2.6896 & 2.8305 & 2.9738 & 1.8115 & 2.6609 & 3.1819 & 3.7508 \\
\hline & May & & 2.5990 & 2.8772 & 3.0279 & 3.1812 & 1.1078 & 1.6272 & 1.9458 & 2.2937 \\
\hline & June & & 1.8647 & 2.0643 & 2.1724 & 2.2824 & 1.7154 & 2.5198 & 3.0131 & 3.5518 \\
\hline & July & & 3.7454 & 4.1463 & 4.3634 & 4.5843 & 1.4670 & 2.1548 & 2.5767 & 3.0374 \\
\hline & August & & 2.7143 & 3.0048 & 3.1621 & 3.3222 & 1.3353 & 1.9614 & 2.3453 & 2.7647 \\
\hline & September & & 2.7699 & 3.0663 & 3.2269 & 3.3903 & 0.8850 & 1.2999 & 1.5544 & 1.8323 \\
\hline & October & & 2.0210 & 2.2373 & 2.3545 & 2.4737 & 0.9276 & 1.3625 & 1.6292 & 1.9205 \\
\hline & November & & 2.4296 & 2.6896 & 2.8305 & 2.9738 & 1.8115 & 2.6609 & 3.1819 & 3.7508 \\
\hline & December & & 4.6900 & 5.1919 & 5.4638 & 5.7404 & 0.7492 & 1.1005 & 1.3159 & 1.5512 \\
\hline \multirow[t]{12}{*}{ Atsbi } & January & 0.28 & 4.3232 & 4.7859 & 5.0366 & 5.2915 & 2.4276 & 3.3019 & 3.8096 & 4.3454 \\
\hline & February & & 4.2743 & 4.7317 & 4.9795 & 5.2316 & 2.6316 & 3.5794 & 4.1298 & 4.7107 \\
\hline & March & & 4.4089 & 4.8808 & 5.1364 & 5.3964 & 2.9278 & 3.9823 & 4.5947 & 5.2409 \\
\hline & April & & 4.0003 & 4.4284 & 4.6603 & 4.8962 & 3.6379 & 4.9481 & 5.7090 & 6.5120 \\
\hline & May & & 4.0134 & 4.4430 & 4.6756 & 4.9123 & 2.8710 & 3.9051 & 4.5055 & 5.1393 \\
\hline & June & & 4.3283 & 4.7915 & 5.0424 & 5.2977 & 3.3241 & 4.5213 & 5.2166 & 5.9503 \\
\hline & July & & 4.2745 & 4.7320 & 4.9798 & 5.2319 & 3.0253 & 4.1150 & 4.7477 & 5.4155 \\
\hline & August & & 4.4089 & 4.8808 & 5.1364 & 5.3964 & 2.9278 & 3.9823 & 4.5947 & 5.2409 \\
\hline & September & & 4.2337 & 4.6868 & 4.9322 & 5.1819 & 2.6216 & 3.5658 & 4.1141 & 4.6927 \\
\hline & October & & 3.7738 & 4.1777 & 4.3965 & 4.6191 & 2.7442 & 3.7325 & 4.3065 & 4.9122 \\
\hline & November & & 4.1554 & 4.6001 & 4.8410 & 5.0861 & 2.5065 & 3.4093 & 3.9335 & 4.4868 \\
\hline & December & & 4.6900 & 5.1919 & 5.4638 & 5.7404 & 2.5617 & 3.4843 & 4.0201 & 4.5856 \\
\hline \multirow[t]{12}{*}{ Chercher } & January & 0.28 & 3.9986 & 4.4266 & 4.6584 & 4.8942 & 2.6787 & 3.6435 & 4.2038 & 4.7950 \\
\hline & February & & 4.1398 & 4.5829 & 4.8229 & 5.0670 & 3.0713 & 4.1775 & 4.8198 & 5.4978 \\
\hline & March & & 4.0535 & 4.4873 & 4.7223 & 4.9614 & 3.2356 & 4.4010 & 5.0777 & 5.7919 \\
\hline & April & & 4.1105 & 4.5504 & 4.7887 & 5.0311 & 3.4717 & 4.7222 & 5.4483 & 6.2146 \\
\hline & May & & 2.9666 & 3.2841 & 3.4561 & 3.6310 & 2.7462 & 3.7353 & 4.3097 & 4.9158 \\
\hline & June & & 4.3182 & 4.7804 & 5.0307 & 5.2854 & 3.1095 & 4.2295 & 4.8798 & 5.5662 \\
\hline & July & & 4.1130 & 4.5532 & 4.7917 & 5.0342 & 3.4147 & 4.6446 & 5.3588 & 6.1125 \\
\hline & August & & 3.4328 & 3.8002 & 3.9992 & 4.2017 & 2.8800 & 3.9173 & 4.5197 & 5.1554 \\
\hline & September & & 2.3286 & 2.5778 & 2.7128 & 2.8501 & 1.8439 & 2.5080 & 2.8937 & 3.3007 \\
\hline & October & & 3.8455 & 4.2570 & 4.4800 & 4.7068 & 2.0912 & 2.8443 & 3.2817 & 3.7433 \\
\hline & November & & 4.3051 & 4.7658 & 5.0154 & 5.2693 & 2.6974 & 3.6690 & 4.2331 & 4.8285 \\
\hline & December & & 3.8484 & 4.2603 & 4.4834 & 4.7104 & 2.7268 & 3.7089 & 4.2792 & 4.8811 \\
\hline
\end{tabular}


Table 7 continued

\begin{tabular}{|c|c|c|c|c|c|c|c|c|c|c|}
\hline \multirow[t]{2}{*}{ Location } & & \multirow[t]{2}{*}{$z$} & \multicolumn{4}{|l|}{$k$} & \multicolumn{4}{|l|}{$c(\mathrm{~m} / \mathrm{s})$} \\
\hline & & & $10 \mathrm{~m}$ & $30 \mathrm{~m}$ & $50 \mathrm{~m}$ & $80 \mathrm{~m}$ & $10 \mathrm{~m}$ & $30 \mathrm{~m}$ & $50 \mathrm{~m}$ & $80 \mathrm{~m}$ \\
\hline \multirow[t]{12}{*}{ Maychew } & January & 0.34 & 4.0945 & 4.5327 & 4.7701 & 5.0115 & 1.2894 & 1.8733 & 2.2286 & 2.6147 \\
\hline & February & & 4.2019 & 4.6516 & 4.8952 & 5.1430 & 1.2604 & 1.8312 & 2.1785 & 2.5560 \\
\hline & March & & 4.0472 & 4.4803 & 4.7149 & 4.9536 & 1.4485 & 2.1044 & 2.5036 & 2.9374 \\
\hline & April & & 4.1644 & 4.6101 & 4.8515 & 5.0971 & 1.5273 & 2.2189 & 2.6398 & 3.0972 \\
\hline & May & & 3.4913 & 3.8649 & 4.0673 & 4.2732 & 1.2293 & 1.7860 & 2.1247 & 2.4929 \\
\hline & June & & 3.3639 & 3.7239 & 3.9190 & 4.1174 & 2.0437 & 2.9692 & 3.5324 & 4.1445 \\
\hline & July & & 3.1193 & 3.4531 & 3.6340 & 3.8179 & 3.0385 & 4.4145 & 5.2518 & 6.1618 \\
\hline & August & & 2.5274 & 2.7979 & 2.9444 & 3.0934 & 2.2501 & 3.2691 & 3.8891 & 4.5630 \\
\hline & September & & 2.3188 & 2.5670 & 2.7014 & 2.8381 & 1.3064 & 1.8980 & 2.2580 & 2.6492 \\
\hline & October & & 4.3457 & 4.8108 & 5.0627 & 5.3190 & 0.9688 & 1.4075 & 1.6744 & 1.9646 \\
\hline & November & & 4.2322 & 4.6851 & 4.9305 & 5.1801 & 0.9800 & 1.4238 & 1.6938 & 1.9873 \\
\hline & December & & 4.5303 & 5.0151 & 5.2778 & 5.5449 & 1.1569 & 1.6808 & 1.9996 & 2.3461 \\
\hline \multirow[t]{12}{*}{ Mekele } & January & 0.26 & 3.7277 & 4.1266 & 4.3427 & 4.5626 & 5.1047 & 6.7923 & 7.7571 & 8.7654 \\
\hline & February & & 3.7012 & 4.0974 & 4.3119 & 4.5302 & 5.2762 & 7.0205 & 8.0177 & 9.0599 \\
\hline & March & & 3.5996 & 3.9849 & 4.1936 & 4.4059 & 5.6160 & 7.4727 & 8.5341 & 9.6434 \\
\hline & April & & 3.9446 & 4.3668 & 4.5955 & 4.8281 & 5.5802 & 7.4251 & 8.4798 & 9.5820 \\
\hline & May & & 3.4722 & 3.8438 & 4.0451 & 4.2499 & 3.8991 & 5.1882 & 5.9252 & 6.6953 \\
\hline & June & & 3.7329 & 4.1324 & 4.3488 & 4.5689 & 2.4934 & 3.3178 & 3.7890 & 4.2815 \\
\hline & July & & 3.7629 & 4.1657 & 4.3838 & 4.6057 & 2.3174 & 3.0835 & 3.5215 & 3.9793 \\
\hline & August & & 3.6524 & 4.0433 & 4.2551 & 4.4705 & 2.1088 & 2.8060 & 3.2045 & 3.6210 \\
\hline & September & & 3.6375 & 4.0268 & 4.2377 & 4.4522 & 1.9027 & 2.5318 & 2.8914 & 3.2672 \\
\hline & October & & 4.0671 & 4.5024 & 4.7382 & 4.9781 & 3.5171 & 4.6798 & 5.3446 & 6.0393 \\
\hline & November & & 3.9021 & 4.3197 & 4.5460 & 4.7761 & 4.0150 & 5.3425 & 6.1013 & 6.8943 \\
\hline & December & & 3.7464 & 4.1473 & 4.3645 & 4.5855 & 4.5729 & 6.0847 & 6.9490 & 7.8522 \\
\hline \multirow[t]{12}{*}{ Senkata } & January & 0.29 & 4.4550 & 4.9318 & 5.1900 & 5.4528 & 2.1089 & 2.9001 & 3.3632 & 3.8543 \\
\hline & February & & 4.1077 & 4.5473 & 4.7854 & 5.0277 & 2.8510 & 3.9207 & 4.5468 & 5.2107 \\
\hline & March & & 4.0203 & 4.4506 & 4.6837 & 4.9208 & 2.5936 & 3.5667 & 4.1362 & 4.7402 \\
\hline & April & & 3.8406 & 4.2516 & 4.4743 & 4.7008 & 3.4536 & 4.7494 & 5.5078 & 6.3121 \\
\hline & May & & 2.9440 & 3.2591 & 3.4298 & 3.6034 & 2.7434 & 3.7727 & 4.3751 & 5.0140 \\
\hline & June & & 3.3286 & 3.6848 & 3.8778 & 4.0741 & 2.5110 & 3.4531 & 4.0045 & 4.5893 \\
\hline & July & & 3.7171 & 4.1149 & 4.3304 & 4.5496 & 1.6743 & 2.3026 & 2.6702 & 3.0601 \\
\hline & August & & 3.1940 & 3.5358 & 3.7210 & 3.9093 & 1.5891 & 2.1854 & 2.5343 & 2.9044 \\
\hline & September & & 2.8560 & 3.1617 & 3.3273 & 3.4957 & 2.1577 & 2.9672 & 3.4410 & 3.9435 \\
\hline & October & & 3.3604 & 3.7200 & 3.9148 & 4.1130 & 2.8124 & 3.8676 & 4.4852 & 5.1402 \\
\hline & November & & 3.5392 & 3.9180 & 4.1232 & 4.3319 & 2.3465 & 3.2269 & 3.7421 & 4.2886 \\
\hline & December & & 3.4475 & 3.8165 & 4.0164 & 4.2197 & 2.2843 & 3.1413 & 3.6429 & 4.1748 \\
\hline \multirow[t]{12}{*}{ Shire } & January & 0.36 & 3.1719 & 3.5114 & 3.6953 & 3.8824 & 0.9589 & 1.4242 & 1.7117 & 2.0273 \\
\hline & February & & 4.0354 & 4.4673 & 4.7012 & 4.9392 & 1.2927 & 1.9198 & 2.3074 & 2.7328 \\
\hline & March & & 3.6173 & 4.0044 & 4.2142 & 4.4275 & 1.3881 & 2.0615 & 2.4777 & 2.9344 \\
\hline & April & & 3.3588 & 3.7183 & 3.9130 & 4.1111 & 1.7018 & 2.5274 & 3.0377 & 3.5977 \\
\hline & May & & 3.0845 & 3.4146 & 3.5934 & 3.7753 & 1.0460 & 1.5535 & 1.8671 & 2.2113 \\
\hline & June & & 3.3780 & 3.7395 & 3.9354 & 4.1346 & 1.3949 & 2.0717 & 2.4899 & 2.9490 \\
\hline & July & & 3.3203 & 3.6757 & 3.8682 & 4.0640 & 1.0412 & 1.5463 & 1.8585 & 2.2011 \\
\hline & August & & 3.5002 & 3.8748 & 4.0777 & 4.2842 & 1.0393 & 1.5436 & 1.8552 & 2.1972 \\
\hline & September & & 3.3089 & 3.6630 & 3.8549 & 4.0500 & 0.8521 & 1.2654 & 1.5209 & 1.8013 \\
\hline & October & & 2.9207 & 3.2333 & 3.4027 & 3.5749 & 0.7472 & 1.1097 & 1.3337 & 1.5796 \\
\hline & November & & 3.3588 & 3.7183 & 3.9130 & 4.1111 & 1.7018 & 2.5274 & 3.0377 & 3.5977 \\
\hline & December & & 4.6900 & 5.1919 & 5.4638 & 5.7404 & 0.7865 & 1.1681 & 1.4039 & 1.6627 \\
\hline
\end{tabular}




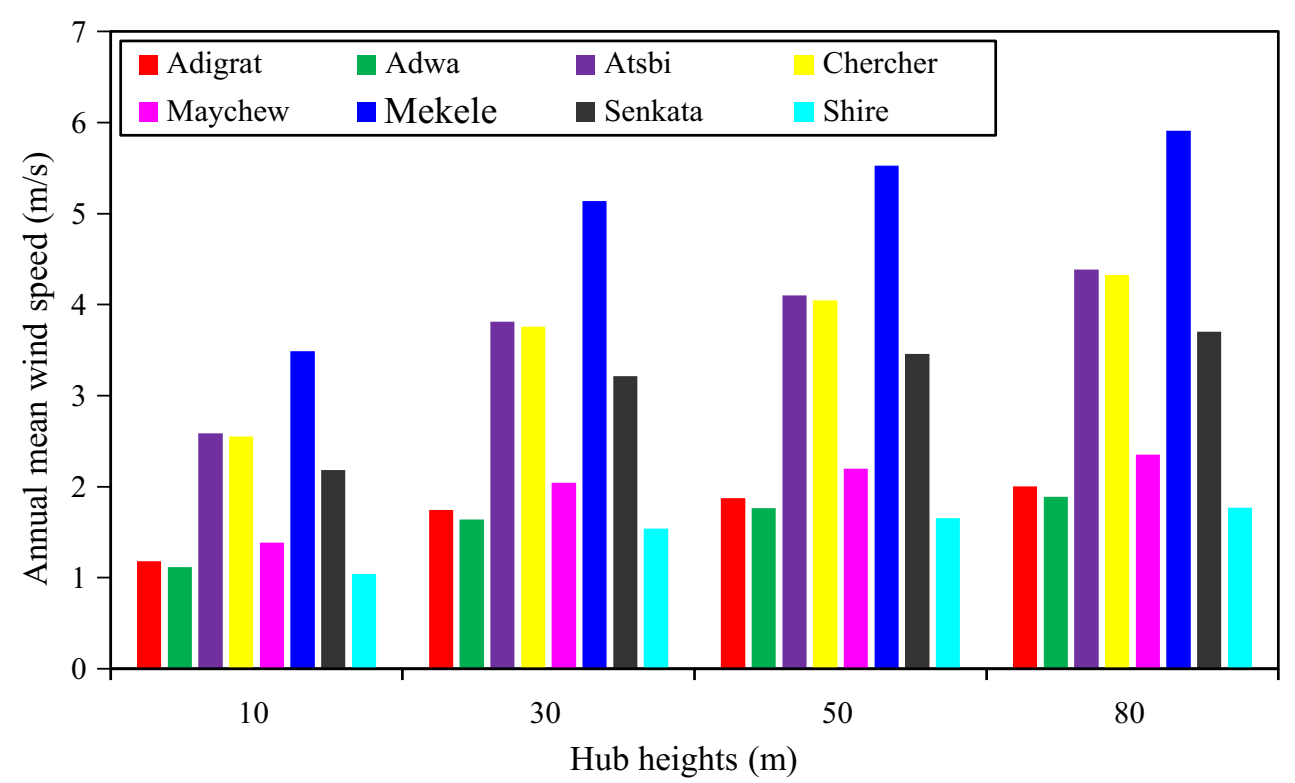

Fig. 3 Annual mean wind speeds for different hub heights

Table 8 Annual power output for the selected WECS in the eight selected locations

\begin{tabular}{|c|c|c|c|c|c|c|c|}
\hline \multirow[t]{2}{*}{ S. no } & \multirow[t]{2}{*}{ Locations } & \multicolumn{2}{|l|}{ POLARIS P15-50 } & \multicolumn{2}{|l|}{ POLARIS P50-500 } & \multicolumn{2}{|l|}{ VESTAS V1 10-2.0 } \\
\hline & & $\begin{array}{l}\text { Annual mean power } \\
\text { output (kW/year) }\end{array}$ & $C_{\mathrm{f}}(\%)$ & $\begin{array}{l}\text { Annual mean power } \\
\text { output (kW/year) }\end{array}$ & $C_{\mathrm{f}}(\%)$ & $\begin{array}{l}\text { Annual mean power } \\
\text { output (kW/year) }\end{array}$ & $C_{\mathrm{f}}(\%)$ \\
\hline 1 & Adigrat & 0.157 & 0.016 & 4.795 & 0.040 & 25.039 & 0.060 \\
\hline 2 & Adwa & 0.160 & 0.035 & 3.936 & 0.071 & 20.299 & 0.096 \\
\hline 3 & Atsbi & 2.420 & 1.032 & 23.248 & 0.722 & 185.249 & 1.385 \\
\hline 4 & Chercher & 2.548 & 1.555 & 24.779 & 1.152 & 189.680 & 2.052 \\
\hline 5 & Maychew & 0.445 & 0.045 & 8.667 & 0.071 & 47.823 & 0.119 \\
\hline 6 & Mekele & 8.246 & 6.067 & 79.815 & 4.333 & 487.766 & 7.873 \\
\hline 7 & Senkata & 1.658 & 0.958 & 16.835 & 0.773 & 113.830 & 1.306 \\
\hline 8 & Shire & 0.033 & 0.002 & 2.205 & 0.010 & 10.605 & 0.014 \\
\hline
\end{tabular}

2015, are 0.4837 Birr (0.02 USD per kWh) (Ethiopian Electric Power Corporation (EEPCo) 2011). In comparison of average cost obtained by EEPCo, Atsbi, Chercher, Mekele and Senkata are the suitable locations to establish all chosen WECS in this study. It can further be suggested that, rural areas where electric grid system is not readily available, profitable applications of wind resources can be obtained with battery charging and water pumping using small-scale mechanical wind pumps.

\section{Conclusions}

In recent years, utilization of renewable energy resources using WECSs for electricity generation has become more prevalent around the globe. However, in the literature, very few studies have concentrated on economic and energetic investigation of these systems, especially in Ethiopia. From the foregoing, the following conclusions are drawn:

- All the selected locations have annual mean wind speeds ranging between 1.044 and $3.488 \mathrm{~m} / \mathrm{s}$ at Shire and Mekele, respectively. Likewise, the maximum annual mean power density and energy densities are obtained as $35.129 \mathrm{~W} / \mathrm{m}^{2}$ and $306.06 \mathrm{kWh} / \mathrm{m}^{2}$ at Mekele, while the minimum values are evaluated as $0.857 \mathrm{~W} / \mathrm{m}^{2}$ and $7.44 \mathrm{kWh} / \mathrm{m}^{2}$ at Shire.

- The highest capacity factor, annual power and energy output were obtained as $7.873 \%$, $487.766 \mathrm{~kW} /$ year and 4272.828 MWh/year using VESTAS V110-2.0 wind turbine model at Mekele, whereas the least is 


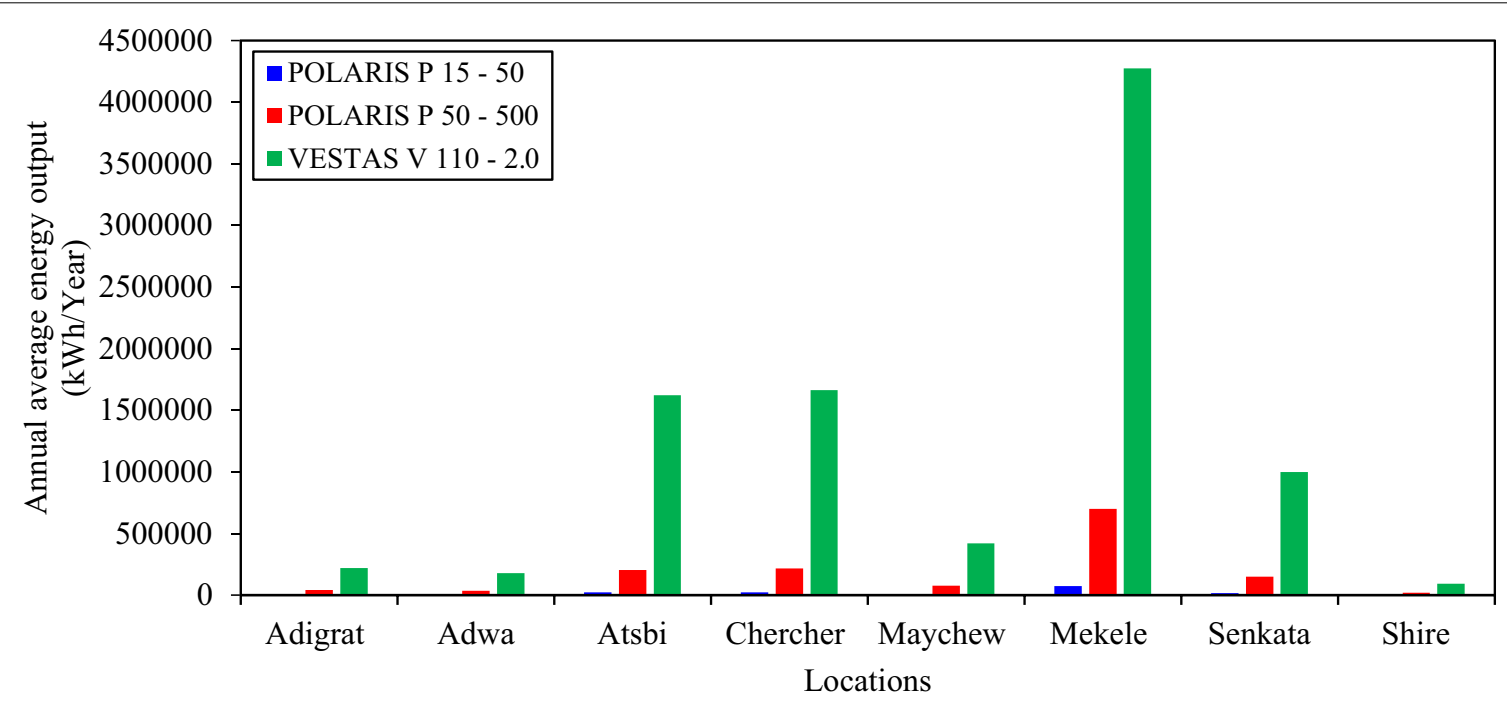

Fig. 4 Annual energy output of WECS in the eight selected locations

Table 9 Analysis of wind energy cost $(\$ / k W h)$ based on PVC

\begin{tabular}{|c|c|c|c|c|c|}
\hline S. no & Location & Turbine models & $\mathrm{PVC}_{\text {min }}$ & $\mathrm{PVC}_{\max }$ & $\mathrm{PVC}_{\text {avg }}$ \\
\hline \multirow[t]{3}{*}{1} & Adigrat & POLARIS P15-50 & 0.5922 & 1.0897 & 0.8410 \\
\hline & & POLARIS P50-500 & 0.1312 & 0.3000 & 0.2156 \\
\hline & & VESTAS V110-2.0 & 0.0876 & 0.2002 & 0.1439 \\
\hline \multirow[t]{3}{*}{2} & Adwa & POLARIS P15-50 & 0.2669 & 0.4911 & 0.3790 \\
\hline & & POLARIS P50-500 & 0.0740 & 0.1691 & 0.1216 \\
\hline & & VESTAS V110-2.0 & 0.0545 & 0.1245 & 0.0895 \\
\hline \multirow[t]{3}{*}{3} & Atsbi & POLARIS P15-50 & 0.0091 & 0.0167 & 0.0129 \\
\hline & & POLARIS P50-500 & 0.0073 & 0.0166 & 0.0119 \\
\hline & & VESTAS V110-2.0 & 0.0038 & 0.0087 & 0.0062 \\
\hline \multirow[t]{3}{*}{4} & Chercher & POLARIS P15-50 & 0.0060 & 0.0111 & 0.0086 \\
\hline & & POLARIS P50-500 & 0.0046 & 0.0104 & 0.0075 \\
\hline & & VESTAS V1 10-2.0 & 0.0026 & 0.0058 & 0.0042 \\
\hline \multirow[t]{3}{*}{5} & Maychew & POLARIS P15-50 & 0.2066 & 0.3801 & 0.2933 \\
\hline & & POLARIS P50-500 & 0.0739 & 0.1688 & 0.1213 \\
\hline & & VESTAS V1 10-2.0 & 0.0440 & 0.1006 & 0.0723 \\
\hline \multirow[t]{3}{*}{6} & Mekele & POLARIS P15-50 & 0.0015 & 0.0028 & 0.0022 \\
\hline & & POLARIS P50-500 & 0.0012 & 0.0028 & 0.0020 \\
\hline & & VESTAS V1 10-2.0 & 0.0007 & 0.0015 & 0.0011 \\
\hline \multirow[t]{3}{*}{7} & Senkata & POLARIS P15-50 & 0.0098 & 0.0180 & 0.0139 \\
\hline & & POLARIS P50-500 & 0.0068 & 0.0155 & 0.0112 \\
\hline & & VESTAS V110-2.0 & 0.0040 & 0.0092 & 0.0066 \\
\hline \multirow[t]{3}{*}{8} & Shire & POLARIS P15-50 & 5.1512 & 9.4783 & 7.3148 \\
\hline & & POLARIS P50-500 & 0.5403 & 1.2350 & 0.8877 \\
\hline & & VESTAS V110-2.0 & 0.3860 & 0.8824 & 0.6342 \\
\hline
\end{tabular}

noted at Shire as $0.002 \%, 0.033 \mathrm{~kW} /$ year and 293.23 kWh/year using POLARIS P15-50.

- Average minimum cost per kWh obtained at Mekele is $0.0011 \$ / \mathrm{kWh}$ using VESTAS V110-2.0, while the highest average cost obtained is $7.3148 \$ / \mathrm{kWh}$ using POLARIS P15-50 at Shire.

- Places like Atsbi, Chercher, Mekele and Senkata could be more profitable sites for electrical and mechanical applications (water pumping and battery charging).

\section{Abbreviations}

EEPCo: Ethiopian Electric Power Corporation; EPF: energy pattern factor; EPFM: energy pattern factor method; GDP: gross domestic product; GEF: global environment facility; GIS: geographical information system; GTP: growth and transformation plan; GWEC: Global Wind Energy Council; LSRM least square regression method; MLM: maximum likelihood method; MOM: method of moments; NMA: National Meteorological Agency; PVC: present value of cost; STDM: standard deviation method; SWERA: solar and wind energy resource assessment; WECS: wind energy conversion system; WPD: wind power density; UNEP: United Nations Environmental Program.

\section{List of symbols}

c Weibull scale parameter $(\mathrm{m} / \mathrm{s})$

$C_{\mathrm{f}} \quad$ capacity factor (\%)

$C_{\mathrm{omr}} \quad$ operation, maintenance and repair cost

$E_{\mathrm{D}} \quad$ annual mean energy density $\left(\mathrm{kWh} / \mathrm{m}^{2}\right)$

$E_{\text {out }} \quad$ energy output (kWh/year)

$E_{\text {rated }}$ rated energy (kWh/year)

$I \quad$ investment cost

$i \quad$ inflation rate

$v \quad$ wind speed $(\mathrm{m} / \mathrm{s})$

$\overline{\bar{v}} \quad$ mean wind speed $(\mathrm{m} / \mathrm{s})$

$\overline{v^{3}} \quad$ mean of wind speed cubes, $\mathrm{m}^{3} / \mathrm{s}^{3}$ 


$\begin{array}{ll}f(v) & \text { Weibull probability distribution function } \\ F(v) & \text { Weibull cumulative distribution function } \\ k & \text { Weibull shape parameter, dimensionless } \\ n & \text { no. of wind speed samples considered } \\ P_{\mathrm{D}} & \text { annual mean power density }\left(\mathrm{W} / \mathrm{m}^{2}\right) \\ P_{\mathrm{r}} & \text { rated power }(\mathrm{kW}) \\ P_{\mathrm{e}, \text { avg }} & \text { average power output }(\mathrm{kWh}) \\ P_{\mathrm{eR}} & \text { rated electrical power }(\mathrm{kW}) \\ Q_{\mathrm{c}} & \text { cut-in wind speed }(\mathrm{m} / \mathrm{s}) \\ Q_{\mathrm{r}} & \text { rated wind speed }(\mathrm{m} / \mathrm{s}) \\ Q_{\mathrm{f}} & \text { cut-off wind speed }(\mathrm{m} / \mathrm{s}) \\ r & \text { interest rate } \\ S & \text { scrap value } \\ t & \text { lifetime of the machine }\end{array}$

\section{Greek letters}

$\propto \quad$ roughness coefficient

$\Gamma() \quad$ gamma function

$P \quad$ air density $\left(\mathrm{kg} / \mathrm{m}^{3}\right)$

\begin{abstract}
Authors' contributions
SPKK was collected the wind data and carried out preliminary analysis. Wind turbine calculations and 'Background' section was drafted by STNG. 'Results and discussion' section was jointly drafted by SPKK and STNG. Both authors read and approved the final manuscript.
\end{abstract}

\section{Authors' information}

SPKK is working as a Lecturer in Department of Civil Engineering, Wollega University, Nekemte, Ethiopia. He obtained Bachelors degree in Civil Engineering from Osmania University (OU), Hyderabad, Masters Degree in Geo-environmental Engineering from JNTUH College of Engineering, Hyderabad. STNG is a Associate professor in Department of Electrical and Computer Engineering, Wollega University, Nekemte, Ethiopia. STNG obtained Bachelors degree in Science from JVR Government Degree College, Sathupally, Khammam, Telangana state, India, and obtained Doctoral degree in Computer Science and Engineering.

\section{Author details}

${ }^{1}$ Department of Electrical and Computer Engineering, College of Engineering and Technology, Wollega University (WU), Nekemte, Oromia Region, Ethiopia. ${ }^{2}$ Department of Civil Engineering, College of Engineering and Technology, Wollega University (WU), Nekemte, Oromia Region, Ethiopia.

\section{Acknowledgements}

The authors are grateful to the National Meteorological Agency (NMA), Mekele, Ethiopia, for their cooperation in providing the raw data.

\section{Competing interests}

The authors declare that they have no competing interests.

Received: 29 October 2015 Accepted: 23 February 2016 Published online: 17 March 2016

\section{References}

Acker, T. L., Williams, S. K., Duque, E. P. N., Brummels, G., \& Buechler, J. (2007). Wind resource assessment in the state of Arizona: Inventory, capacity factor, and cost. Renewable Energy, 32, 1453-1466.
Adaramola, M. S., Paul, S. S., \& Oyedepo, S. O. (2011). Assessment of electricity generation and energy cost of wind energy conversion systems in northcentral Nigeria. Energy Conversion and Management, 52(12), 3363-3368.

Akdag, S. A., Bagiorgas, H. S., \& Mihalakakou, G. (2010). Use of two-component Weibull mixtures in the analysis of wind speed in the Eastern Mediterranean. Applied Energy, 87, 2566-2573.

Akdag, S. A., \& Dinler, A. (2009). A new method to estimate Weibull parameters for wind energy applications. Energy Conversion and Management, 50, $1761-1766$.

Akdag, S. A., \& Guler, O. (2010). Evaluation of wind energy investment interest and electricity generation cost analysis for Turkey. Applied Energy, 87, 2574-2580.

Akpinar, E. K., \& Akpinar, S. (2005). An assessment on seasonal analysis of wind energy characteristics and wind turbine characteristics. Energy Conversion and Management, 46, 1848-1867.

Bagiorgas, H. S., Assimakopoulos, M. N., Theoharopoulos, D., Matthopoulos, D., \& Mihalakakou, G. K. (2007). Electricity generation using wind energy conversion systems in the area of Western Greece. Energy Conversion and Management, 48, 1640-1655.

Balouktsis, A., Chassapis, D., \& Karapantsios, T. D. (2002). A nomogram method for estimating the energy produced by wind turbine generators. Solar Energy, 72, 251-259.

Bekele, G., \& Palm, B. (2009). Wind energy potential assessment at four typical locations in Ethiopia. Applied Energy, 86(3), 388-396.

Breyer, Ch., Gerlach, A., Hlusiak, M., Peters, C., Adelmann, P., Winiecki, J., et al. (2009). Electrifying the poor: Highly economic off-grid PV systems in Ethiopia a basis for sustainable development. http://www.arcfinance.org/ pdfs/news/EthiopiaPaper2009.pdf.

Burton, T., Sharpe, D., Jenkins, N., \& Bossanyi, E. (2001). Wind energy handbook. Chichester: Wiley.

Centre for Wind Energy Technology. (2011). Course material: Seventh international training course on wind turbine technology and applications from Aug. 2011. 3-26. Chennai: C-WET.

CESEN-ANSALDO. (1986). Wind energy resources. Technical report 4. Ethiopian Nation Energy Committee.

Chang, T. J., \& Tu, Y. L. (2007). Evaluation of monthly capacity factor of WECS using chronological and probabilistic wind speed data: A case study of Taiwan. Renewable Energy, 32, 1999-2010.

Dalelo, A. (2003). Rural electrification in Ethiopia opportunities and bottlenecks. Addis Ababa University. http://www.zef.de/fileadmin/webfiles/renewables/presentations/Dalelo_rural\%20electrification\%20ethiopia.pdf.

Elliott, D. L., Holladay, C. G., Barchet, W. R., Foote, H. P., \& Sandusky, W. F. (1987). Wind energy resource atlas of the United States. DOE/CH10094-4.

Ethiopian Electric Power Corporation (EEPCO). (2011). Strategic management and programming. Facts in brief. http://www.eepco.gov.et/files/.../ RPF\%20ENREP\%20Main\%20document.doc.

Ethiopian Resource Group (ERG). (2009). Diversity and security for the Ethiopian power system. A preliminary assessment of risks and opportunities for the power sector.

Ethiopian Rural Energy Development and Promotion Center. (2007). Final report on country background information, solar and wind energy utilization and project development scenarios. Addis Ababa.

Genç, M. S., \& Gökçek, M. (2009). Evaluation of wind characteristics and energy potential in Kayseri, Turkey. Journal of Energy Engineering, 135(2), 1-11.

Getachew, B., \& Getnet, T. (2012). Feasibility study of small Hydro/PV/Wind hybrid system for off-grid rural electrification in Ethiopia. Applied Energy, 97, 5-15.

Growth and Transformation Plan (GTP). (2010). Ministry of Finance and Economic Development (MoFED). Addis Ababa.

Habali, S. M., Mohammed, A. Hamdan, Bassan, A. J., \& Adnan, I. O. Z. (1987). Wind speed and wind energy potential of Jordan. Solar Energy, 38, 59-70.

Hadagu, A. (2006). Status and trends of Ethiopian rural electrification fund. http://www.bgr.de/geotherm/ArGeoC1/pdf/07\%20A.\%20Hadgu\%20 status\%20of\%20Ethiopian\%20Electrification\%20fund.pdf.

Hau, E. (2006). Wind turbines — fundamental, Technologies, applications, economics (2nd ed., pp. 752-772). Berlin, Heidelberg: Springer.

Jowder, F. A. L. (2009). Wind power analysis and site matching of wind turbine generators in Kingdom of Bahrain. Applied Energy, 86(4), 538-545.

Justus, C. G., Hargraves, W. R., Mikhail, A., \& Graber, D. (1978). Methods for estimating wind speed frequency distributions. Journal of Applied Meteorology, 17, 350-353. 
Mathew, S. (2006). Wind energy: Fundamentals, resource analysis and economics. Heidelberg: Springer.

Ministry of Water and Energy (MoWE). (2011). Energy sector mapping and database development (ESMAD), first phase report. http://ergethiopia. com/energy-sector-mapping-and-database-development-esmad/.

Mulugeta, B. A., Aleksandar, S., Dragan, K., \& Slobodan, S. (2013). Wind energy resource development in Ethiopia as an alternative energy future beyond the dominant hydropower. Renewable and Sustainable Energy Reviews, 23, 366-378.

Murat, G., \& Mustafa Seedar, G. (2009). Evaluation of electricity generation and energy cost of wind energy conversion systems (WECSs) in Central Turkey. Applied Energy, 86, 2731-2739.

Ohunakin, O. S., Adaramola, M. S., \& Oyewola, O. M. (2011). Wind energy evaluation for electricity generation using WECS in seven selected locations in Nigeria. Applied Energy, 88(9), 3197-3206.

Ouammi, A., Dagdougui, H., Sacile, R., \& Mimet, A. (2010). Monthly and seasonal assessment of wind energy characteristics at four monitored locations in Liguria region (Italy). Renewable and Sustainable Energy Reviews, 14, 1959-1968.

Redlinger, R. Y., Andersen, P. D., \& Morthorst, P. E. (2006). Wind energy in the 21st century: Economics, policy, technology and the changing electricity industry (1st ed., pp. 73-96). New York: Palgrave.
Rehman, S., El-Amin, I. M., Ahmad, F., Shaahid, S. M., Al-Shehri, A. M., \& Bakhashwain, J. M. (2007). Wind power resource assessment for Rafha, Saudi Arabia. Renewable and Sustainable Energy Reviews, 11, 937-950.

Rocha, P. A. C., de Sousa, R. C., de Andrade, C. F., \& da Silva, M. E. V. (2012). Comparison of seven numerical methods for determining Weibull parameters for wind energy generation in the northeast region of Brazil. Applied Energy, 89(1), 395-400.

RETScreen-Software online user manual, Catalogue no.: M39-104/2004E-PDF. Minister of Natural Resources, Canada, 1997-2004. ISBN 0-662-36820-7.

Sarkar, M., \& Hussain, M. (1991). The potential of wind electricity generation in Bangladesh. Renewable Energy, 1, 855-857.

Shata, A. S. A., \& Hanitsch, R. (2006). Evaluation of wind energy potential and electricity generation on the coast of Mediterranean Sea in Egypt. Renewable Energy, 32, 1183-1202.

Shiva Prashanth, K., \& Satyanarayana, G. (2015). Statistical scrutiny of Weibull parameters for wind energy potential appraisal in the area of northern Ethiopia. Renewables: Wind, Water and Solar, 14(2), 1-15.

Ucar, A., \& Balo, F. (2009). Evaluation of wind energy potential and electricity generation at six locations in Turkey. Applied Energy, 86, 1864-1872.

\section{Submit your manuscript to a SpringerOpen ${ }^{\odot}$ journal and benefit from:}

- Convenient online submission

- Rigorous peer review

- Immediate publication on acceptance

- Open access: articles freely available online

- High visibility within the field

- Retaining the copyright to your article

Submit your next manuscript at $>$ springeropen.com 